\title{
Effects of warm-up and stretching on the peak torque using electromyography - A randomized controlled clinical trial
}

\author{
Cláudio Natanael de Camargo ${ }^{1}$, Juliane de Lima $^{1}$, Marcelo Eduardo Corrêa ${ }^{1}$, Pedro Luiz Fiuza Seninski ${ }^{1}$, Jéssica da Cruz ${ }^{2}, V_{i v i a n e}$ \\ Eloisa Bini ${ }^{3}$, Luiz Alfredo Braun Ferreira ${ }^{1}$, Wagner Menna Pereira ${ }^{1}$
}

${ }^{1}$ Faculdades Guairacá (SESG), Guarapuava (PR), Brazil; ${ }^{2}$ Universidade Estadual do Centro-Oeste, Guarapuava (PR), Brazil; ${ }^{3}$ Universidade Estadual do Centro-

Oeste, Irati (PR), Brazil.

\begin{abstract}
Background: Muscle strength is defined as the muscle's ability to produce maximum tension and torque. For the muscle to reach a maximum voluntary isometric contraction (MVIC), it is necessary to prepare the muscle using stretching, resulting in an increase in the range of motion. Warm-up is popularly used in the practice of physical activity, and its main objective is to achieve an increase in body and muscle temperature, leading the cardiovascular system to a more effective motor activity. Electromyography is used to quantify the electrical activity and the strength (kgf) in the analysis of the maximum strength of a given muscle. Objectives: To analyze the maximum strength (peak torque) of the posterior thigh muscles before and after a warm-up and stretching protocol. Methods: Twenty-three (23) healthy subjects, both genders, with no history of musculoskeletal injury in the lower limbs in the last six months, aged between 18 and 33 years old, were evaluated by electromyography, and randomly distributed in Control group $(n=10)$, Warm-up group $(n=6)$ and Stretching group $(n=7)$. The control group was only evaluated, whereas the other two groups underwent 10 interventions for 5 weeks and after that all were reevaluated. The warm-up group performed exercises on a treadmill for 15 minutes/intervention with controlled speed reaching $70 \%$ of its maximum capacity. The stretching group performed static stretching of the posterior thigh muscles for 20 minutes/intervention. Results: There was a significant increase in the peak torque of the posterior thigh muscles in the warm-up group $(p=0.04)$, and a significant decrease in the stretching group $(p=0.01)$, in the control group there was no significant difference $(p=0.08)$. Conclusion: It was concluded that the warm-up performed on the treadmill was effective in improving the peak torque and muscle strength of the hamstrings.

Keywords: Warm-up exercise; Muscle stretching exercise; Torque; Hamstring muscles.
\end{abstract}

\section{BACKGROUND}

Surface electromyography (EMG) allows the study of the electrical activity of motor neurons and captures the action and potential of the muscles. It is a non-invasive technique for assessing and monitoring muscle activity with electrodes that capture the signal from muscle fibers, helping to identify the peak isometric torque of a given muscle group ${ }^{(1,2)}$. Electromyographic evaluation is able to assess the maximum capacity of activation of the muscle, from a maximum contraction ${ }^{(3)}$, detecting when a muscle becomes active, how long it remains active and whether there is a low or a high muscle contraction activity ${ }^{(4)}$. According to Varrecchia et al. ${ }^{(5)}$, Muscle coactivation is the mechanism that regulates the time and amplitude of the simultaneous activity of the antagonistic muscles around the same joint, varying along the phases of gait, speed and torque. Peak torque is defined as the maximum resistance force during a repetition, becoming an indicator of the capacity of muscle strength, using this variable to assess muscle strength ${ }^{(6)}$. Currently, physical exercises are used in physiotherapy as prevention to improve the quality of muscle strength and the quality of life of subjects ${ }^{(7,8)}$, warm-up exercises and stretching elements are used in the conditioning of physical activities ${ }^{(9)}$, and these should be part of the routine of each person ${ }^{(7,8)}$. Strength trainings are perfected with the use of various warm-up techniques, including general warmup performed on a treadmill, specific warm-up performed before training and passive warm-up, using compresses and baths. The benefits of warming-up are the increase in muscle temperature and energy metabolism, as well as increased tissue elasticity improving the function of the central nervous system and the recruitment of neuromuscular motor units $^{(10,11)}$, that generate gains in muscle strength, hypertrophy of the musculoskeletal system, improvement in sports performance and gains in physical conditioning ${ }^{(6)}$. Bley, Nardi and Marchetti ${ }^{(12)}$, claim that stretching before exercise decreases isometric or dynamic strength, electromyographic activity and peak concentric torque. According to Nogueira et al. ${ }^{(13)}$, stretching aims to increase mobility and expandability of soft tissues, making range of motion more effective, as well as helping to reduce spasm. The present study aimed to assess the peak torque using electromyography in the hamstring muscles, after a stretching and warm-up protocol in healthy subjects. 


\section{METHODS}

The recruitment of subjects was done through disclosures on social media, with academics from falcuty Guairacá and were oriented on the objective of the present study in accordance with National Health Council (466/2012), thus agreeing and signing the Informed Consent Term (IC) approved by the Ethics and Local Research Committee with protocol 2.787.228. The analysis included a total of 40 subjects, 7 of whom were excluded for not being availability, 5 for not meeting the inclusion criteria and 5 for being absent excessively. The sample consisted of 23 subjects aged between 19 and 33 years, of both genders, healthy, who met the inclusion criteria: classified as active through the International Physical Activity Questionnaire (IPAQ); with no history of musculoskeletal injuries of the dominant limb in the last six months; with musculoskeletal injuries; with neurodegenerative, vasomotor or cardiac pathologies. Participants underwent surface electromyography assessment to measure the peak torque of the hamstring muscles. The volunteers were randomly assigned to 3 groups. Control group $(n=10)$, Stretching group $(n=7)$ and warm-up group $(n=6)$ and were referred for electromyography evaluation. The steps performed are in the flowchart (Figure 1). The work was carried out on the premises of Guairacá Integrated Clinics in the faculty Guairacá located in the City of Guarapuava, Paraná, with the prior authorization of those responsible. In data collection, trichotomy and skin cleaning were performed to avoid impedance ${ }^{(14)}$. The electrodes were positioned on motor points of the posterior thigh muscles, halfway between the ischial tuberosity to the popliteal line, and the volunteers were in the prone position, with the hip stabilized by the examiner and with the knee of the dominant limb flexed at $90^{\circ}$ and attached to the load cell, to record the electromyographic activity of the muscles, using the SENIAM protocol ${ }^{(15)}$ (Surface ElectroMyoGraphy for the Non-Invasive Assessment of Muscles) was performed the test with maximum force with the load cell in isometry for 60 seconds (Figure 2:a), in which the patients remained lying down with the fixed load cell. The capture of the electromyographic signal was performed by an electromyography device with 8 channels and bipolar electrodes of active surface type (Figure 2:b), passed through a $20-500 \mathrm{~Hz}$ bandpass filter, amplified in 1,000 times. The data were converted to a 12-bitz A / D plate with a sample frequency of $2,000 \mathrm{~Hz}$. All subjects were initially evaluated using electromyography, and after the intervention period, they were reevaluated.

The sample was randomly divided in stretching, warm-up and control group. The stretching group performed static stretching of the hamstring muscles for 60 seconds each, with 10 variations for 20 minutes (Figure 3 ) and the warm-up group did the same on a treadmill for 15 minutes maintaining $70 \%$ of their maximum physical capacity using the Karvonen equation (220 - age $\times 70 \%$ ), thus standardizing that all warm-up participants reach their submaximal frequency $(70 \%)$, in which they could not walk or run, but reach an average speed between both, controlled by an oximeter ${ }^{(9,16)}$. The control group did not perform any intervention. The assessment of the peak torque was performed through the maximum voluntary isometric contraction of the posterior thigh muscles of the dominant limb, for 60 seconds. The limb was fixed with a chain to the load cell and the knee at a neutral position of $90^{\circ}$. In the load cell, the force is captured electronically, amplified and transmitted to a register monitor, measured in the Newton unit $^{(17)}$.

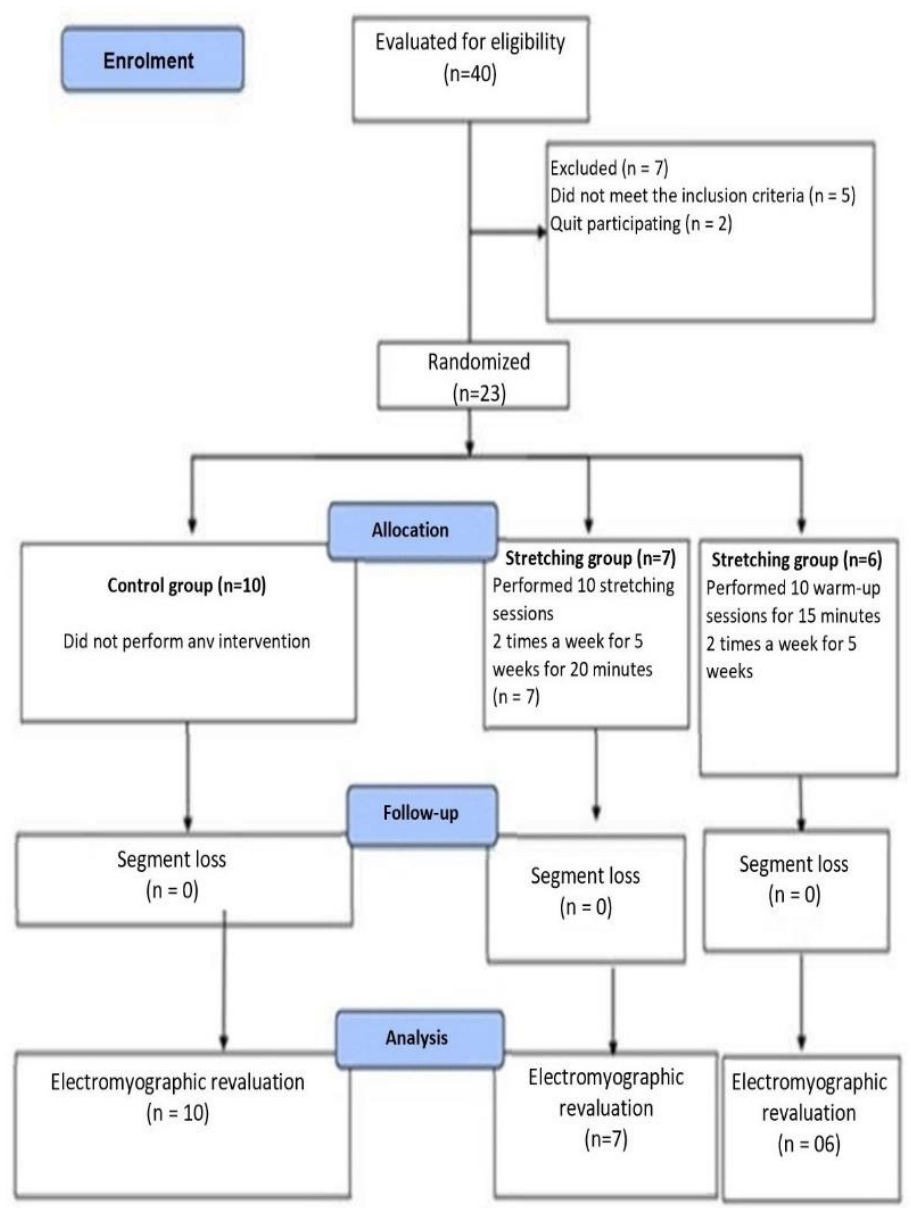

Figure 1. Flowchart of the steps according to CONSORT.

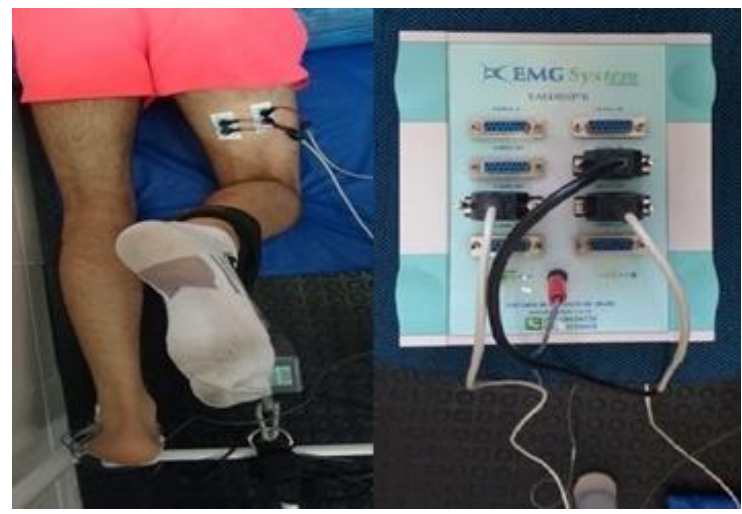

Figure 2. a) Positioning of electrodes on the patient and Force Cell; b) 8-channel electromyography (EMG System Brasil Ltda.), with the subject in prone position, under a hip stabilization roller and attached to a strength load cell with knee flexion at $90^{\circ}$ for a better analysis of the posterior thigh muscles. 


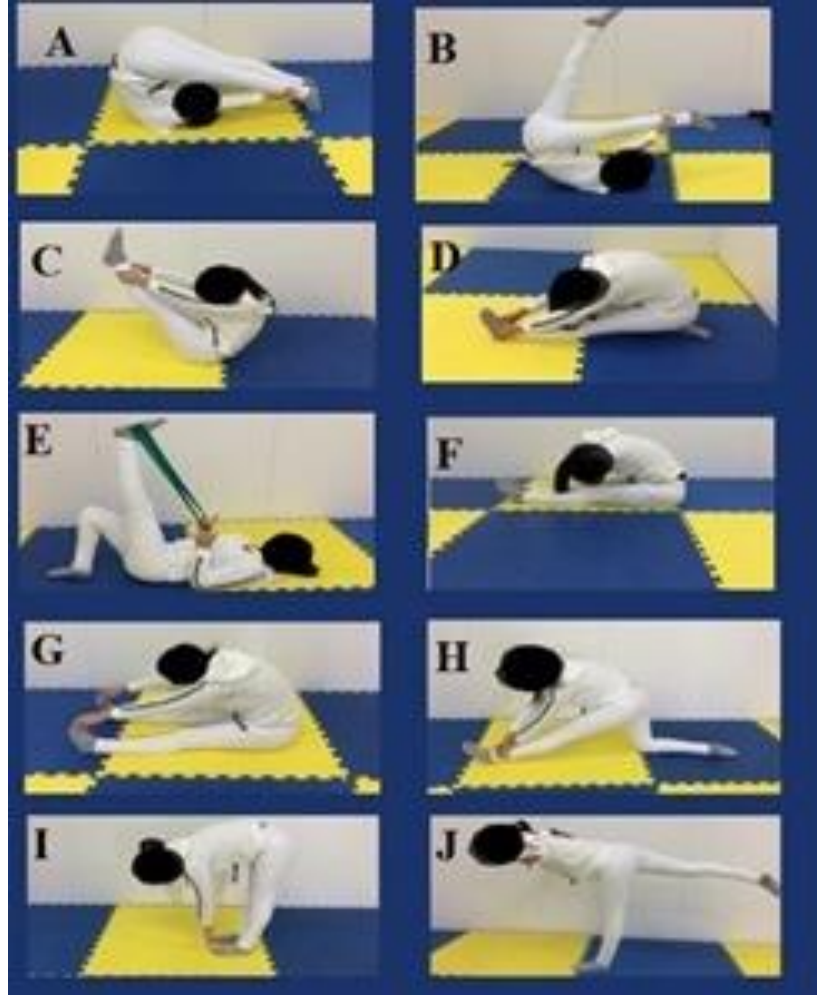

Figure 3. a) Roll over; b) The control balance; c) Teaser; d) Variation Spine Strech forward; e) Hamstring stretch; f) Neck pull; g) Spine stretch; h) Variation Spine Strech forward; i) Back stretches; j) Airplane.

\section{RESULTS}

The anthropometric characteristics are described in Table 1. A statistical comparison was made between the groups, for sample homogeneity. For statistical analysis, the SPSS (version 21) was used. To test normality, a Shapiro-Wilk test (95\%) was performed, and as the samples showed parametric behavior, the $T$ test was used for comparison before and after each group. There was a significant increase in the peak torque of the hamstring muscles in the warm-up group $(p=0.04)$, and a significant decrease in the stretching group ( $p=0.01)$. In the control group, there was no significant difference $(p=0.08)$, as shown in figure 4 .

Table 1. Mean (standard deviation) of the anthropometrical characteristics of the subjects in the warm-up, stretching and control group.

\begin{tabular}{lllll}
\hline Variables & $\begin{array}{l}\text { Warm-up } \\
\text { group }\end{array}$ & $\begin{array}{l}\text { Stretching } \\
\text { group }\end{array}$ & $\begin{array}{l}\text { Control } \\
\text { group }\end{array}$ & $\begin{array}{l}\text { Statistic } \\
(\mathrm{p} \leq 0.05)\end{array}$ \\
\hline $\begin{array}{l}\text { Subjects } \\
\text { Male / }\end{array}$ & 6 & 7 & 10 & \\
$\begin{array}{l}\text { Female } \\
\text { Age }\end{array}$ & $04 / \mathrm{fev}$ & $02 / \mathrm{mai}$ & $05 / \mathrm{mai}$ & \\
$\begin{array}{l}\text { (years) } \\
\text { Weight }\end{array}$ & $26.3(3.50)$ & $24.33(3.72)$ & $23.9(3.31)$ & 0.10 \\
$\begin{array}{l}\text { (Kg) } \\
\text { Height (m) }\end{array}$ & $\begin{array}{l}(11.22) \\
\text { Bgl }\end{array}$ & $69.42(5.18)$ & $\begin{array}{l}75.12 \\
(12.75)\end{array}$ & 0.08 \\
$\begin{array}{l}\text { BMI } \\
\left(\mathrm{Kg} / \mathrm{m}^{2}\right)\end{array}$ & $26.8(3.61)$ & $1.68(0.04)$ & $1.72(0.10)$ & 0.12 \\
\hline
\end{tabular}

\section{Peak Electromyographic Torque}

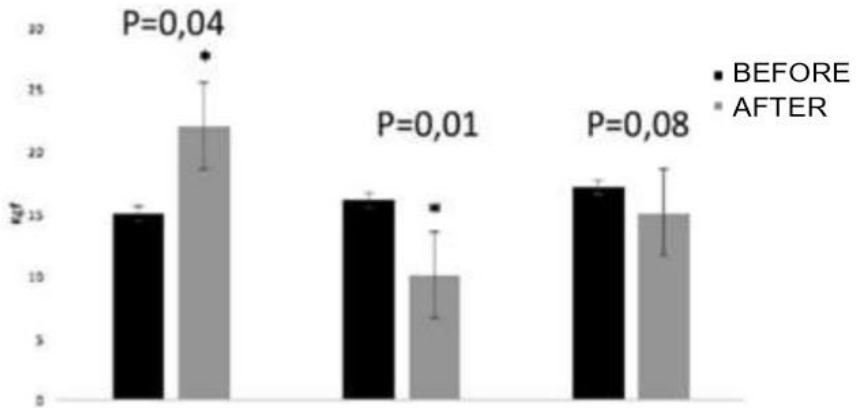

Figure 4. Electromyography of peak torque of the hamstrings (Kgf), before and after warm-up, stretching and control. Note: *Statistical significance of $T$ test $(p<0.05)$.

\section{DISCUSSION}

Alencar and Matias ${ }^{(10)}$, observed that warming-up enables a more dynamic functioning of the organism and muscles, and it should be progressive, with the potential to improve performance, besides it provides an increase in cardiac output and peripheral blood flow, improving the recruitment of neuromuscular motor units. Findings from the present study demonstrate a significant increase in the warm-up group, in addition, they suggest that together with the benefits pointed out by the aforementioned authors, the performance of warm-up generates an increase in the peak electromyographic torque, making it possible to add that the improvement in blood supply and the neovascularization imposed by the increase in vascular caliber and, consequently, of myofibrils, increases the ability to generate electromyographic torque, being effective in short-term activities with contractions of 60 seconds. According to Nogueira et al. ${ }^{(13)}$ the effect of warming up and pre-exercise stretching can compromise muscle activity to produce maximum strength. Their study involved the participation of 60 female volunteers, all healthy, sedentary and with some level of recreational activity and performed only one session and reassessed five minutes after, divided in 4 groups: control, warm-up, stretching and warming-up associated with stretching. Their results demonstrated that there was no significant influence on the amplitude of muscle activation in any evaluated group, coming in line with the present study that also found no significant influence, but a decrease in the strength of the evaluated musculature. Vieira and Rosa(4), stated that the general active warming-up provides a more dynamic functioning of the organism as a whole, whose action mobilizes large muscle groups, thus corroborating with the present study that is based on such physiology and that the subjects performed warming-up for 15 minutes on a treadmill, until reaching their submaximal capacity, this being done by the Karvonen formula (220 - age $\times$ 70\%). Cunha et al. ${ }^{(9)}$ performed 15 minutes of warm-up on the treadmill and argues that the speed of the nervous impulse increases as a result of the warm-up, which can help with a higher reaction speed, therefore greater strength, and not too intense, involving the muscles that will be used to perform the exercise. 
Alvim et al. ${ }^{(18)}$, applied a series of two minutes of passive static stretching, maintaining posture at the point of greatest discomfort, and in the other, four series of 30 seconds for 6 sessions, their findings, analyzed that both stretching routines promoted a significant increase in levels of ROM, without inducing harmful effects on the performance of the force. Elucidating the present research, in which in its results, the stretching group demonstrated a statistical decrease suggesting that the warm-up increases the peak of strength and the stretching decreases, being that possibly the volumes of the stretching protocol may be a relevant factor in the loss of strength, and this occurs due to neural and mechanical factors decreasing the activation of motor units and changes in the viscoelastic properties of the muscle. The range of motion is defined as a greater movement in the execution of a motor act, providing adaptations in the viscoelastic properties of the tendon muscle unit, the maximum force is defined as the greatest amount of force to perform it, in the shortest possible time ${ }^{(19,20)}$. Both studies mentioned above agree that flexibility exercises compromise the performance of strength, and stretching is not advisable before activities that require high levels of strength, however, stretching combined with strength exercises can significantly increase their levels, which corroborated with the present study, since the subjects who performed the stretching showed a significant decrease in peak torque when comparing pre and post interventions. A study of Bastos et al. ${ }^{(21)}$ compared maximum muscle strength, their sample consisted of 30 subjects divided into 2 groups: static stretching group (SG = 15) and group without stretching ( $C G=15)$, both evaluated their peak maximum strength and their results indicated that there was no influence of stretching in strength. Findings in the study of Sereflogu et al. ${ }^{(22)}$ analyzed 20 athletes, who performed 4 sets of static stretches for 30 seconds each, and the rest interval between the four repetitions and between the two unassisted stretching routines was 20 and 30 seconds, respectively. Thus, the time interval for hamstring and quadriceps muscles was $7 \pm$ 1 minutes total, and they demonstrated that there was no significant increase in static and dynamic stretching, having no effect on muscle strength and electromyographic activity. The limitations of the present study are related to the short time of interventions, the limited number of samples and the lack of long-term follow-up to verify the effects of the techniques imposed late. Further studies with a larger sample size are suggested for a longer period of time.

\section{CONCLUSION}

It was concluded through the present study that the warm-up twice a week for 5 weeks was effective in increasing the hamstrings peak torque and after 10 stretching sessions twice a week for 5 weeks there was a decrease in the hamstrings peak torque in comparison to the control group.

\section{AUTHORS' CONTRIBUTION:}

CNC and JL contributed to the elaboration of the design, development of the study and data acquisition. MEC and PLZS contributed to article design and data tabulation. JC and VEB contributed to the critical review, correction and approval of the final version. LABF and WMP contributed to the elaboration of the study design and development and data analysis, and approval of the final version.

FINANCIAL SUPPORT: nothing to declare.

CONFLICT OF INTEREST: the authors declare that they have no conflict of interest.

\section{REFERENCES}

1. Fukuda TY, Echeimberg JO, Pompeu JE, Lucareli PRG, Garbelotti S, Gimenes RO, et al. Root mean square value of the electromyographic signal in the isometric torque of the quadriceps, hamstrings and brachial biceps muscles in female subjects. The Journal of Applied Research. 2010;10(1):32-39.

2. Mello MCVA, Silva LRW, Bonow CA, Vaz MR. Eletromiografia de superfície da região cervical contribuição para a saúde muscular. Acta Paulista de Enfermagem. 2017;30(5):512-19.

3. Burden A. How should we normalize electromyograms obtained from healthy participants? What we have learned from over 25 years of research. Journal of electromyography and kinesiology. 2010;20(6):102335.

4. Vieira LP, Rosa CGS. Influência do aquecimento e alongamento na redução da força e potência muscular ao exercício resistido: Revisão bibliográfica. Amazônia: Science \& Health. 2014;2(3):38-43.

5. Varrecchia T, Rinaldi M, Draicchio F, Conte C, Conforto S, Schmid M, Ranavolo A. Global lower limb muscle coactivation during walking at different speeds: Relationship between spatio-temporal, kinematic, kinetic, and energetic parameters. Journal of Electromyography and Kinesiology. Journal of electromyography and kinesiology. 2018;43:148-57.

6. Do Couto MC, Sales RM, Rodrigues MAB, Laurentino GEC, Filho AG. Coativação e pico de torque dos músculos extensores e flexores do joelho em indivíduos hemiparéticos crônicos nas posições sentada e supina. Fisioterapia e Pesquisa. 2014;22(4):411-19.

7. Cardoso JHP, Damasceno SO, Camara DT, Miranda FHS, Assis LC, Silva EAL, et al. Análise de encurtamento dos músculos isquiotibiais em adultos jovens de 18 a 25 anos. Colloquium Vitae. 2016; 8:90-96.

8. Tillaar RVD, Solheim JAV, Bencke J. Comparison of hamstring muscle activation during high-speed running and various hamstring strengthening exercises. The International Journal of Sports Physical Therapy. 2017;12(5):718-27.

9. Cunha FG, Assad AR, Pereira TJCC, Pinheiro PIS, 
Barbosa GM, Lins CAA, et al. Efeito do aquecimento sobre a flexibilidade e o desempenho funcional: ensaio clínico randomizado. Rev Bras Med Esporte. 2017;23(5):385-89.

10. Alencar TA, Matias KFS. Princípios fisiológicos do aquecimento e alongamento muscular na atividade esportiva. Rev Bras Med Esport. 2010;16(3):230-34.

11. Albuquerque CV, Maschio JP, Gruber CR, Souza RM, Hernandez S. Efeito agudo de diferentes formas de aquecimento sobre a força muscular. Fisioter Mov. 2011;24(2):221-29.

12. Bley AS, Nardi OS, Marchetti PH. Alongamento passivo agudo não afeta a atividade muscular máxima dos ísquiotibiais. Motricidade. 2012;8(4):80-86.

13. Nogueira JFS, Lins CAA, Souza AVC, Brasileiro JS. Efeitos do aquecimento e do alongamento na resposta neuromuscular dos isquiotibiais. Rev Bras Med Esporte. 2014;20(4):262-66.

14. Suzuki FS, Kalytczak MM, Palomare RAF, Paunksnis MR, Silva SM, Politi F, et al. Alterations in peak torque occur without hematological changes after muscle fatigue. Rev Bras Med Esporte. 2017;23(3):180-83.

15. SENIAM 8. European Recommendations for Surface ElectroMyoGraphy. Results of the SENIAM project. Hermens HJ, Freriks B, Merletti R, Stegeman D, Blok J, Rau G, et al. Published by. Roessingh Research and Development, Enschede, the Netherlands, 1999, ISBN 90-75452-15-2.
16. She J, Nakamura H, Ohyama Y, Makino K, Hashimoto $\mathrm{H}$. Selection of Suitable Maximum-heart-rate Formulas for Use with Karvonen Formula to Calculate Exercise Intensity. International Journal of Automation and Computing. 2015;12(1)62-69.

17. Barbosa AM, Camassuti PADS, Tamanini G, Marcolino AM, Barbosa RI, Fonseca MDCR. Reliability and validity of a load cell device for hand grip strength assessment. Fisioterapia e Pesquisa. 2015;22(4):378-85.

18. Alvim FC, Rezende YM, Silva TK, César EP. Comparação de dois protocolos de alongamento para amplitude de movimento e força dinâmica. Rev Bras Med Esporte. 2018;24(1):20-25.

19. Amaral SO, Ribeiro WR, Castro OH, Peixoto GC, Leite RD, Pires FO. Efeito de uma sessão de alongamento passivo estático sobre a flexibilidade e desempenhos de força máxima e potência. RBPFEX-Revista Brasileira de Prescrição e Fisiologia do Exercício. 2016;10(59):377-85.

20. Ferrari GD, Arroyo CT. Efeito de treinamentos de flexibilidade sobre a força e o torque muscular: uma revisão crítica. Revista Brasileira de Ciência e Movimento. 2013;21(2):151-62.

21. Bastos CLB, Rosário ACSD, Portal MDND, Neto GR, Silva AJ, Novaes JDS. Influência aguda do alongamento estático no comportamento da força muscular máxima. Motricidade. 2014;10(2):90-99.

22. Serefoglu A, Sekir U, Gür H, AKOVA B. Effects of static and dynamic stretching on the isokinetic peak torques and electromyographic activities of the antagonist muscles. Journal of sports science \& medicine.2017;16(1):6-13. 